\title{
Superactive human leptin antagonist (SHLA), triple Lan1 and quadruple Lan2 leptin mutein as a promising treatment for human folliculoma
}

\author{
E. Fiedor ${ }^{1}$ E. L. Gregoraszczuk ${ }^{1}$
}

Received: 15 May 2017 / Accepted: 15 August 2017 / Published online: 31 August 2017

(C) The Author(s) 2017. This article is an open access publication

\begin{abstract}
Purpose There are no data showing a direct correlation between obesity and increased blood leptin levels with folliculoma. Moreover, folliculoma is not the best studied among other ovarian cancer types. We investigated whether oestradiol can modulate ObR expression in some oestrogen-responsive tissues and that leptin exerts its activity not only via the leptin receptor but also through cross talk with other signalling systems. We hypothesise that blocking ObR expression could be a novel treatment for gonadal ovarian cancer.

Methods We evaluated the effect of SHLA, Lan1 and Lan2 blockers on cell proliferation (BrdU incorporation assay), ObR and ER $\alpha / \beta$ gene expression (qPCR), oestradiol secretion (ELISA) and cell cycle protein expression (Western blot) in the non-cancerous cell line $\mathrm{HGrCl}$ and
\end{abstract}

two granulosa cancer cell lines: the juvenile form (COV434) and the adult form (KGN).

Results ObR gene expression in cancer cell lines was $50 \%$ higher than in the non-cancer cells. Lan-1 and Lan-2 decreased ObR expression in COV434, while it had no effect in KGN cells. Higher ER $\beta$ expression in non-cancer and higher ER $\alpha$ expression in both cancer cell lines was noted. SHLA and Lan-1 changed the ratio towards greater expression of $E R \beta$, characteristic of non-cancer granulosa cells. All ObR antagonists in $\mathrm{HCrC} 1$ and $\mathrm{KGN}$ but only Lan-2 in COV434 reversed leptin-stimulated proliferation. In both non-cancer and cancer granulosa cells, leptin acts as a cyclinD/cdk4, cyclin $\mathrm{A} / \mathrm{cdk} 2$ and $\mathrm{E} 2 \mathrm{~F}$ inhibitor.

Conclusion These results indicate that SHLA and Lan2 are promising leptin receptor inhibitors that can eliminate the negative effects of leptin. These compounds should be considered in further ex vivo studies on the cancer microenvironment.

E. L. Gregoraszczuk

ewa.gregoraszczuk@uj.edu.pl

1 Department of Physiology and Toxicology of Reproduction, Institute of Zoology and Biomedical Research, Jagiellonian University, Gronostajowa 9, 30-387 Kraków, Poland 


\section{Graphical abstract}

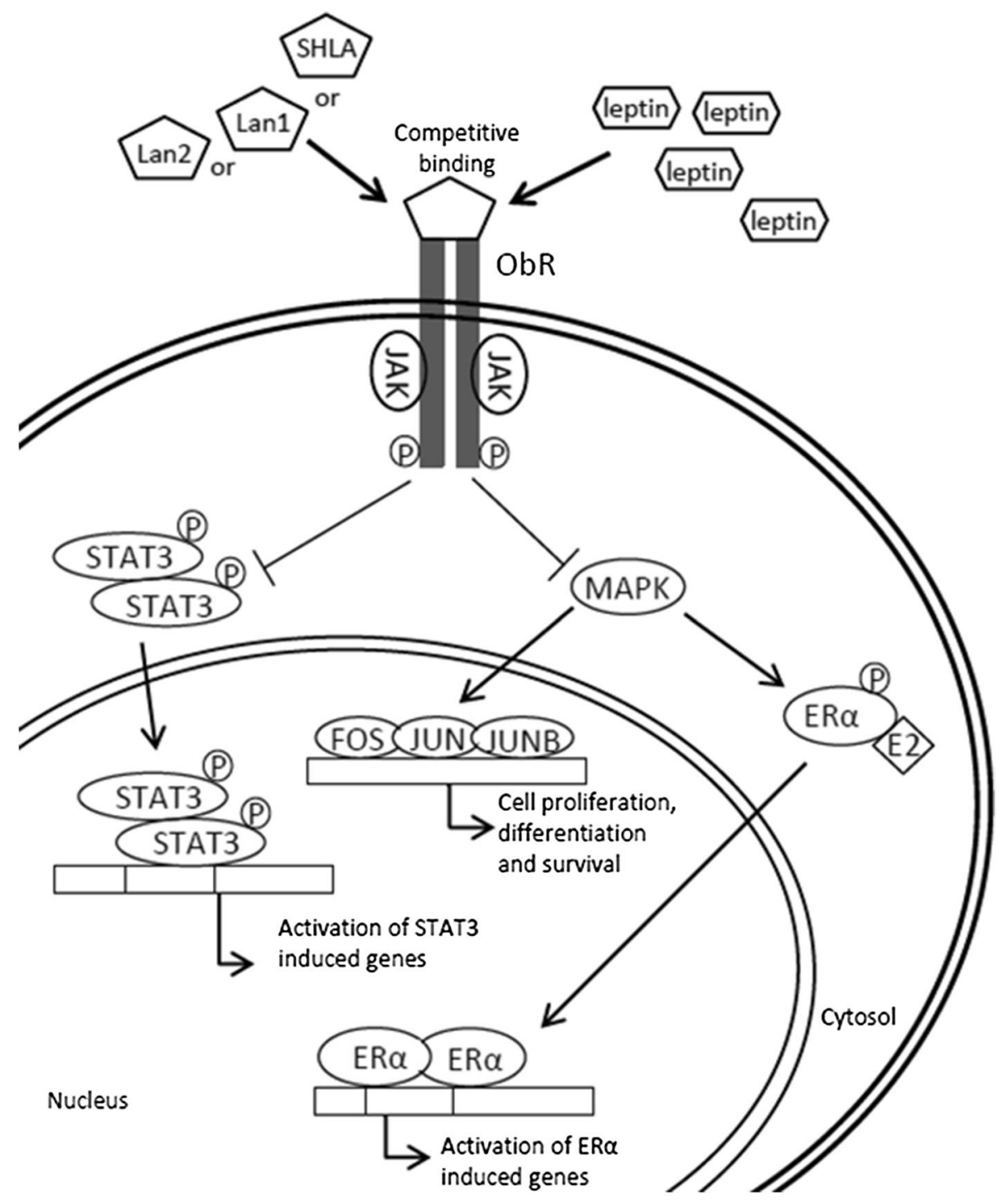

Keywords Folliculoma cells $\cdot$ Leptin receptor antagonists $\cdot$ ObR expression $\cdot$ ER $\alpha / E R \beta$ expression $\cdot$ Cell cycle protein expression

\section{Introduction}

Leptin is a small $(16 \mathrm{kDa})$ protein produced and secreted by adipose tissue, which is involved in appetite regulation, bone formation and reproductive function. Recent studies have demonstrated that this hormone stimulates growth, migration, invasion and angiogenesis in tumour cell models, suggesting that leptin is capable of promoting an aggressive cancer phenotype [1]. Epidemiological studies have indicated a positive correlation between obesity and an increased risk of several types of cancer [2]. Serum leptin levels have been reported to be higher in overweight and obese women than in women with normal weight. In obese individuals, leptin levels can reach $40 \mathrm{ng} / \mathrm{mL}$, which is up to ten times higher than in normal weight people [3,4]. Cancer risk is higher among overweight and obese people, with an increased risk of 16 and 30\%, respectively [5]. Moreover, leptin and its receptors are over-expressed in different human cancers [1]. Leptin has been proposed as one of the six markers of ovarian cancer [6]. Uddin et al. revealed a significant association between ObR overexpression and poor survival rates in $59.2 \%$ of epithelial ovarian cancer cases [7].

Granulosa cell tumours constitute the second largest group of ovarian tumours (approximately, 25-30\%), with tumours derived from epithelial cells accounting for approximately 70\% [8]. Granulosa cell tumours can be divided into two histopathological forms: a mature form, diagnosed most 
frequently in peri-menopausal women (95\%), and a juvenile form, diagnosed in young women and girls who have aged prematurely (5\% of cases) [9]. Despite the fact that granulosa cell tumours can be successfully treated by surgery, relapses are often observed and further adjuvant treatment is still not possible.

To our knowledge, there are no data showing a direct correlation between obesity and folliculomas. Moreover, folliculoma is not well studied among the ovarian cancer types, although both the short (ObRa) and long (ObRb) forms of the leptin receptor are present in human granulosa cells [10, 11]. Löffler et al. [10] showed that, in polycystic ovaries, leptin-positive cells were noted both in the hypertrophied theca layer and in the luteinised granulosa layer. Taking into consideration that leptin at a supraphysiological concentration, as noted in obese women, has stimulatory effects on testosterone secretion characteristic of polycystic ovarian syndrome correlated with obesity [12], we hypothesised that, as in the case of epithelial ovarian cancer, ObR overexpression in granulosa cell tumours could be correlated with the incidence of granulosa cell cancer, and leptin receptor blockers might be used as an adjuvant therapy.

Currently, several groups of scientists are working on the synthesis of molecules that block ObR. A number of leptin receptor antagonists have been synthesised for therapeutic use, with several completing pre-clinical testing [13], indicating their possible use in anticancer therapy. In previous studies using different epithelial cancer cell lines, we showed that SHLA and quadruple leptin mutein, Lan2 (L39A/D40A/F41A/I42A), had no effect on non-cancerous HOSEpiC cell proliferation [14]. However, both antagonists reversed the stimulatory effect of leptin on metastatic carcinoma $\mathrm{CaOV}-3$ cell proliferation to control levels and even below control levels in chemoresistant OVCAR-3 cells. Leptin receptor antagonists have been investigated in breast and prostate cancers, which mainly are hormone dependent. It has been shown that Aca1, Allo-aca and D-ser can inhibit leptin-stimulated proliferation in MCF-7 breast cancer cells [15]. Another leptin receptor antagonist, LDFI (Leu-AspPhe-Ile), is also able to inhibit the proliferation of MCF-7 cells in vitro and in vivo [16]. The antagonist Lan1 is able to inhibit the phosphorylation of leptin-signalling proteins Jak2, ERK1/2 and Akt, in PC3 and DU145 prostate cancer cell lines [17]. In a previously published study using epithelial ovarian cancer cell lines, we investigated the effect of SHLA and Lan 2 on the JAK/Stat3, MAPK/ERK and PI3K/ Akt pathways and showed an inhibitory effect of SHLA on all tested signalling proteins in OVCAR-3 cells and of Lan2 on Stat 3 and ERK1/2 proteins in CaOV-3 cells [14]. These data point to a similar signalling pathway in the antagonistic effects of leptin receptor blockers.

In the present study, we evaluated the effect of leptin and three of its receptor antagonists: Lan1 (L39A/D40A/
F41A mutant), Lan2 (L39A/D40A/F41A/I42A mutant) and SHLA (D23L/L39A/D40A/F41A mutant) on leptin and oestradiol receptor gene and protein expression, cell proliferation including cell cycle protein expression, caspase-3 activity and oestradiol secretion in two granulosa tumour cell lines. The two cell lines were COV434, representing the juvenile form of granulosa tumour, and the steroidogenic human ovarian granulosa-like tumour (KGN), representing the adult type of this cancer (corresponding to peri- to postmenopausal age). The human immortalised non-luteinised granulosa cell line HGrC1 was used as the control.

Based on the fact that leptin exerts its activity not only through the leptin receptor (ObR), but also through cross talk with other signalling systems implicated in tumour genesis $[18,19]$, in this study we focused our attention on the relationship between the leptin/ObR axis and oestrogen receptors $(\mathrm{ER} \alpha / \beta)$.

Taking into consideration that oestradiol can modulate ObR expression in some oestrogen-responsive tissues, we hypothesised that blocking ObR expression could be a novel treatment for granulosa ovarian cancer.

\section{Materials and methods}

\section{Reagents}

Dulbecco's modified Eagle's medium/Nutrient Mixture F-12 (DMEM/F-12) was obtained from Gibco by Thermo Fisher Scientific (Waltham, MA, USA). DMEM, foetal bovine serum (FBS, heat inactivated), penicillin and streptomycin were obtained from Sigma Chemical Co. (St. Louis, MO, USA). All applied media were oestradiol free. Leptin was obtained from Sigma Chemical Co. (St. Louis, MO, USA). Leptin receptor antagonists (SHLA, Lan1 and Lan2) were obtained from Protein Laboratories Rehovot (PLR) Ltd. (Rehovot, Israel). All antagonists have the same specificity. They interact with the cytokine homology domain 2 in the leptin receptor and do not interact with IGD (immunoglobulin-like domain) of the receptor, as the 39-40, 39-41 or 39-42 Ala mutation abolished this interaction [20].

\section{Cell culture}

HGrC1 (human non-luteinised granulosa cell line) cells were a gift from Dr Ikara Iwase (Nagoya University, Japan) and cultured according to the protocol described by Bayasula et al. [21]. HGrC1 may possess the characteristics of granulosa cells in early stage follicles. A human immortalised non-luteinised granulosa cell line (HGrC1) originally derived from mural granulosa cells expresses the FSH receptor and is responsive to the transforming growth factor (TGF)- $\beta$ superfamily and FSH, retaining its original 
granulosa cell character and function. $\mathrm{HGrC} 1$ might also be capable of growth transition from a gonadotrophin-independent status to gonadotrophin-dependent one, but they are not capable of undergoing luteinisation.

COV434 cells were obtained from the Sigma Chemical Co. (St. Louis, MO, USA). The biological characteristics of this cell line include production of $17 \beta$-oestradiol in response to $\mathrm{FSH}$, absence of the LH receptor, no luteinisation capability and the presence of specific molecular markers of apoptosis enabling the induction of follicular atresia [22].

KGN cells were obtained from Masatoshi Nomura and Hajime Nawata, Kyushu University, Japan. With luteinisation capability, they constitute a useful model for understanding the regulation of steroidogenesis, cell growth and apoptosis in human granulosa cells [23].

HGrC1 and COV434 cells were routinely cultured in DMEM $+2 \mathrm{mM}$ glutamine $+10 \%$ FBS. KGN cells were routinely cultured in DMEM/F-12 + 10\% FBS. Cells were grown in $75 \mathrm{~cm}^{2}$ tissue culture dishes (Nunc, Denmark) in a $37{ }^{\circ} \mathrm{C}$ incubator with a humidified mixture of $5 \% \mathrm{CO}_{2}: 95 \%$ air.

\section{Experimental procedure}

\section{qPCR analysis}

Basal ObR gene expression and expression of the ObR gene under the influence of leptin and leptin antagonists was determined by qPCR. Cells were seeded into 96-well culture plates at a density of $5 \times 10^{3}$ cells/well ( $\left.\mathrm{HGrC} 1\right)$, $8 \times 10^{3}$ cells/well (COV434) and $1.5 \times 10^{4}$ cells/well (KGN) taking into consideration the size of the cells and the population doubling time. The next day, the medium was changed and cells were treated with leptin at a dose of $40 \mathrm{ng} / \mathrm{mL}$ and SHLA, Lan1 and Lan2 at a dose of $1000 \mathrm{ng} / \mathrm{mL}$ with leptin at a dose of $40 \mathrm{ng} / \mathrm{mL}$ for $24 \mathrm{~h}$. Doses of leptin were chosen based on literature data [3, 4]. Total RNA isolation and cDNA synthesis was performed using the TaqMan Gene Expression Cell-to-CT Kit (Applied Biosystems, Carlsbad, CA, USA) in accordance with the manufacturer's protocol. Amplifications were performed using the StepOnePlus system (Applied Biosystems, Carlsbad, CA, USA) and the TaqMan Leptin Receptor primer (Cat. No. Hs00174497_ $\mathrm{m} 1$ ), oestrogen receptor $\alpha$ primer (Hs00174860) and oestrogen receptor $\beta$ primer (Hs01100353) in combination with the TaqMan Gene Expression Master Mix (Applied Biosystems, Carlsbad, CA, USA), in accordance with the manufacturer's instructions.

A PCR was performed using a final volume of $20 \mu \mathrm{L}$, including $100 \mathrm{ng} /$ reaction cDNA. PCR conditions were as follows: pre-incubation $\left(2 \mathrm{~min}\right.$ at $50{ }^{\circ} \mathrm{C}$ and $10 \mathrm{~min}$ at $95^{\circ} \mathrm{C}$ ), amplification for 40 cycles $\left(15 \mathrm{~s}\right.$ at $95^{\circ} \mathrm{C}$ and $1 \mathrm{~min}$ at $60{ }^{\circ} \mathrm{C}$ ). The relative expression of genes was normalised against the endogenous reference gene GAPDH (Human GAPD Endogenous Control, number 4333764F) $(\Delta \mathrm{Cq})$ and converted to relative expression using the $2^{-\Delta \Delta \mathrm{Cq}}$ method. The results are expressed as relative values (RQ).

\section{Western blot analysis}

Cells were plated into 24-well plates at a density of $2.5 \times 10^{4}$ ( $\mathrm{HGrC} 1$ cells), $3 \times 10^{4}$ (COV434 cells) and $6 \times 10^{4}(\mathrm{KGN}$ cells) and allowed to attach overnight. The following day, the media were changed and cells were treated with $40 \mu \mathrm{g} /$ $\mathrm{mL}$ leptin alone or in combination with $1000 \mu \mathrm{g} / \mathrm{mL}$ SHLA, Lan1 or Lan2. To examine cell cycle protein expression, cells were incubated for $48 \mathrm{~h}$. After incubation, cells were washed with ice-cold PBS and lysed with Laemmli lysis buffer (Sigma Chemical Co., St. Louis, MO, USA). The lysed cells were then scraped, transferred to microtubes and stored at $-70{ }^{\circ} \mathrm{C}$ until analysis.

Prior to analysis, samples were sonicated and centrifuged at $15,000 \times g$ for $15 \mathrm{~min}$ at $4{ }^{\circ} \mathrm{C}$. The quantity of protein was determined using the Bradford method and the clear supernatant was used for electrophoresis. Equal amounts of protein $(100 \mu \mathrm{g})$ from each treatment group were separated by SDS-PAGE and transferred to PVDF membranes using a Bio-Rad Mini-Protean 3 apparatus (Bio-Rad Laboratories Inc., Hercules, CA, USA). The blots were blocked for $1 \mathrm{~h}$ in 5\% BSA with $0.1 \%$ Tween-20 in $0.02 \mathrm{M}$ TBS buffer. Blots were incubated overnight with primary antibodies specific to ObR (ab5593, Abcam, Cambridge, Great Britain) at a dilution of 1:2000, cyclin D1 (\#2978, Cell Signaling Technology Inc., Beverly, MA, USA), cdk4 (\#12790), cdk2 (\#2546), cyclin A2 (\#4656) at a 1:1000 dilution and E2F-1 (sc-251 Santa Cruz Biotechnology Inc., Santa Cruz, CA, USA), E2F-2 (sc-633), ER $\alpha$ (sc-8002) and ER $\beta$ (sc-6822) at a dilution of 1:200. After incubation with the primary antibody, the membranes were washed three times with $0.1 \%$ Tween-20 in $0.02 \mathrm{M}$ TBS buffer and incubated for $1 \mathrm{~h}$ with an appropriate horseradish peroxidase-conjugated secondary antibody (\#7074 or \#7076, Cell Signaling Technology Inc., Beverly, MA, USA; dilution 1:2000).

$\beta$-Actin was used as an internal loading control; membranes were washed for $30 \mathrm{~min}$ in stripping buffer $(0.25 \mathrm{M}$ glycine, $1 \%$ SDS, pH 2) and reprobed by overnight incubation with primary antibodies specific to $\beta$-actin (A5316, Sigma Chemical Co., St. Louis, MO, USA; dilution 1:2000) and for $1 \mathrm{~h}$ with a horseradish peroxidase-conjugated secondary antibody (P0447 DAKO, Glostrup, Denmark; dilution 1:5000).

Immunopositive bands were visualised using Western Blotting Luminol Reagent (Santa Cruz Biotechnology Inc., Santa Cruz, CA, USA) and ChemiDoc ${ }^{\mathrm{TM}}$ XRS+ System (Bio-Rad Laboratories Inc., Hercules, CA, USA). Relative 
levels of protein expression were determined using ImageJ software (US National Institutes of Health, Bethesda, MD, USA). Individual protein levels were normalised to $\beta$-actin controls and the ratio of protein to $\beta$-actin was normalised to 1 in the untreated control group.

\section{Cell proliferation BrdU assay}

DNA synthesis in proliferating cells was determined by measuring bromodeoxyuridine (BrdU) incorporation with the commercial Cell Proliferation ELISA System (Roche Molecular Biochemicals, Mannheim, Germany). The cells were seeded in 96-well culture plates at a density of $5 \times 10^{3}$ cells/well $(\mathrm{HGrC} 1), 8 \times 10^{3}$ cells/well (COV434) and $1.2 \times 10^{4}$ cells/well (KGN). Leptin was added at a concentration of $40 \mathrm{ng} / \mathrm{mL}$. Leptin receptor antagonists were added at concentrations of 10,100 or $1000 \mathrm{ng} / \mathrm{mL}$, with leptin at a concentration of $40 \mathrm{ng} / \mathrm{mL}$. Cells were cultured for $48 \mathrm{~h}$ with repeated exposure; the culture medium was changed daily and fresh compounds added. After $48 \mathrm{~h}$, the medium was removed and cells were incubated for $3 \mathrm{~h}$ with a BrdU labelling solution, containing $10 \mu \mathrm{M} \mathrm{BrdU}$. The assay was performed according to the manufacturer's instructions. Absorbance values were measured at $450 \mathrm{~nm}$ using an ELISA reader (ELx808 BIO-TEK Instruments, Vinooski, VT, USA). The culture medium alone was used as a control for non-specific binding.

\section{Caspase-3 activity assay}

HGrC1 cells were seeded in 96-well culture plates at a density of $5 \times 10^{3}$ cells/well, COV434 cells at a density of $8 \times 10^{3}$ cells/well and KGN cells at a density of $1.2 \times 10^{4}$ cells per well. Leptin receptor antagonists were added at concentrations of 10,100 or $1000 \mathrm{ng} / \mathrm{mL}$, with leptin at a concentration of $40 \mathrm{ng} / \mathrm{mL}$. Cells were cultured for $48 \mathrm{~h}$ with repeated exposure. The culture medium was changed daily and fresh compounds were added. After exposure, the medium was removed and the plates were stored at $-70{ }^{\circ} \mathrm{C}$. Cells were lysed in buffer containing $50 \mathrm{mM}$ HEPES, $100 \mathrm{mM} \mathrm{NaCl}, 0.1 \%$ CHAPS, $1 \mathrm{mM}$ EDTA, $10 \%$ glycerol and $10 \mathrm{mM}$ DTT. The assay was carried out by adding $20 \mathrm{M}$ of Ac DEVD-AMC, a substrate for the fluorometric determination of caspase-3 activity. Reaction mixtures were incubated at $37^{\circ} \mathrm{C}$. After $3 \mathrm{~h}$, fluorescence was measured at $360 \mathrm{~nm}$ excitation and $460 \mathrm{~nm}$ emission using a microELISA plate reader (Bio-Tek Instruments).

\section{Oestradiol secretion performed by the ELISA method}

HGrC1 cells were seeded in 96-well culture plates at a density of $5 \times 10^{3}$ cells/well, COV434 cells at a density of $8 \times 10^{3}$ cells/well and KGN cells at a density of $1.2 \times 10^{4}$ cells/well. Leptin receptor antagonists were added at concentrations of 10,100 or $1000 \mathrm{ng} / \mathrm{mL}$, with leptin at a concentration of $40 \mathrm{ng} / \mathrm{mL}$. Cells were cultured for $48 \mathrm{~h}$ with repeated exposure. The culture medium was changed daily and fresh compounds were added. Androstenedione $\left(10^{-5} \mathrm{M}\right)$ was used as a substrate for oestradiol production. After $48 \mathrm{~h}$, the media were collected and stored at $-20{ }^{\circ} \mathrm{C}$ until analysis. Oestradiol concentrations in the medium were measured by enzyme immunoassay (EIA) using a commercially available ELISA kit (DRG Diagnostic, Germany). All samples were run in duplicate in the same assay. The analytical sensitivity was $10.6 \mathrm{pg} / \mathrm{mL}$. The intra-assay variation was $8.7-9.23 \%$, and the inter-assay variation was $6.87-14.91 \%$. The range of the oestradiol (E2) assay was $10.6-2000 \mathrm{pg} / \mathrm{ml}$.

\section{Statistical analysis}

Data were expressed as mean \pm SEM from the four independent experiments performed in triplicate. Statistical analyses were performed using GraphPad Prism 5. Data were analysed using a one-way analysis of variance (ANOVA) followed by Tukey's honestly significant difference (HSD) multiple range test. A value of $P<0.05$ was considered to be statistically significant.

\section{Results}

\section{The action of SHLA, Lan1 and Lan2 on leptin-stimulated leptin receptor (ObR) gene and protein in different cell lines}

The basal leptin receptor gene expression varied between different cell lines. Assuming the gene expression in $\mathrm{HGrC1}$ cell to be 1, ObR gene expression in COV434 and KGN cells was $50 \%$ higher (Fig. 1a), while there were no differences in ObR protein expression (Fig. 1b).

In non-cancerous $\mathrm{HGrC} 1$ cells, leptin $(40 \mathrm{ng} / \mathrm{mL})$ decreased ObR gene expression, had no effect on ObRb, but increased ObRa protein expression. In both cancer cell lines, COV434 and KGN, leptin slightly increased gene expression but had no effect on both $\mathrm{ObRb}$ and $\mathrm{ObRa}$ protein expression (Fig. 1c, d).

In $\mathrm{HGrC1}$ cells, all three antagonists increased ObR gene expression (Fig. 2a), reversing the inhibitory effect of leptin on ObR gene expression (Fig. 1c), but had no effect on protein expression (Fig. 2b). None of the antagonists affected ObR gene expression in COV434 and KGN cells (Fig. 2c, e). The inhibitory effects of Lan 1 and Lan 2 on both forms of ObR protein expression were observed in COV434 cells (Fig. 2d). In KGN cells, none of the ObR antagonists investigated had an effect on ObR protein expression (Fig. 2f). 


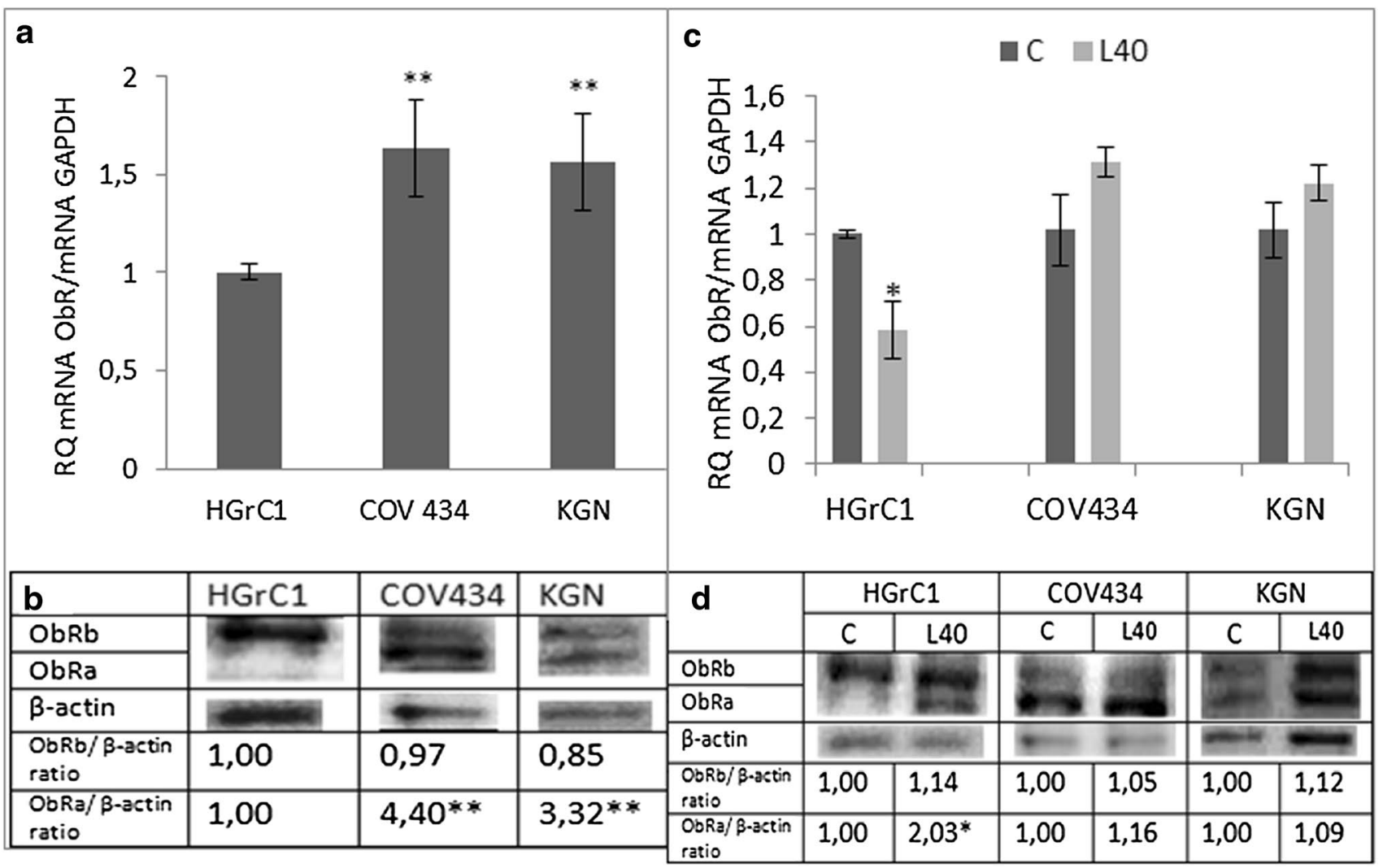

Fig. 1 Basal expression of leptin receptor (ObR) a gene and b protein, and leptin action on ObR $\mathbf{c}$ gene and $\mathbf{d}$ protein expression in different cell lines. Basal mRNA was evaluated by qPCR after $24 \mathrm{~h}$ of cell culture and by Western blot after $48 \mathrm{~h}$. All the results were normalised to $\mathrm{HGrC1}$ (ObR expression) with a value equal to 1 . Values

The action of SHLA, Lan1 and Lan2 on leptin-stimulated expression of oestrogen receptor (ER) gene and protein in different cell lines

The basal expression of the $\mathrm{ER} \beta$ form in $\mathrm{HGrC} 1$ cells was twofold greater than the ER $\alpha$ form at both the gene and protein levels (Fig. 3a, b). In contrast, in the cancer cell lines, both gene and protein ER $\beta$ expressions were higher than those of the ER $\alpha$ form (Fig. 3a, b).

Leptin $(40 \mathrm{ng} / \mathrm{mL})$ decreased both $\mathrm{ER} \alpha$ and $\mathrm{ER} \beta$ gene expression in $\mathrm{HGrC1}$ cells, but had no effect on protein levels. In cancer cells, the expression of ER gene (Fig. 3c) and protein (Fig. 3d) in COV434 and KGN cells was unchanged by the addition of leptin.

In $\mathrm{HGrC} 1$ cells, all three leptin receptor blockers increased $\mathrm{ER} \alpha$ gene expression, but had no effect on ER $\beta$ gene expression (Fig. 4a). None of the antagonists affected $E R \alpha$ protein expression, although an inhibitory effect of Lan 1 and Lan 2 on ER $\beta$ protein expression was observed (Fig. 4b). In COV434 cells, SHLA decreased ER $\alpha$ gene expression and ER $\beta$ protein expression, but had no effect on are mean \pm SEM. Statistically significant differences between groups are indicated by $*(p<0.05)$ and $* *(p<0.01)$. Densitometry results were normalised to $\beta$-actin loading controls to obtain a band ratio. All values marked with $* *(p<0.01)$ are significantly different from the control

ER $\beta$ gene expression. Lan1 increased ER $\beta$ gene expression and decreased ER $\beta$ protein expression, while Lan 2 had the opposite effect (Fig. 4c, d). In KGN cells, all three blockers failed to affect ER $\alpha$ gene expression (Fig. 4e) but reduced $E R \alpha$ protein level (Fig. 4f). No effect on ER $\beta$ gene or protein expression was observed in KGN cells (Fig. 4e, f).

\section{Effect of leptin receptor antagonists on proliferation, caspase- 3 activity and oestradiol secretion}

In $\mathrm{HGrC} 1$ cells, leptin increased cell proliferation (80\%) but had no effect on caspase- 3 activity and slightly increased estradiol secretion (30\%). All three leptin receptor blockers decreased BrdU incorporation (Fig. 5a), except that Lan2 at the highest concentration $(1000 \mathrm{ng} / \mathrm{mL}$; Fig. $5 \mathrm{~d})$ had no effect on caspase-3 activity. Lan1 $(1000 \mathrm{ng} / \mathrm{mL})$ and Lan2 (10 and $100 \mathrm{ng} / \mathrm{mL}$ ) reduced oestradiol secretion (Fig. $5 \mathrm{~g}$ ).

In COV434 cells, SHLA and Lan2 at dose $1000 \mathrm{ng} / \mathrm{mL}$ decreased BrdU incorporation, while Lan1 had no effect (Fig. 5b). None of the blockers investigated had an effect on caspase-3 activity (Fig. 5e) or oestradiol secretion (Fig. 5h). 


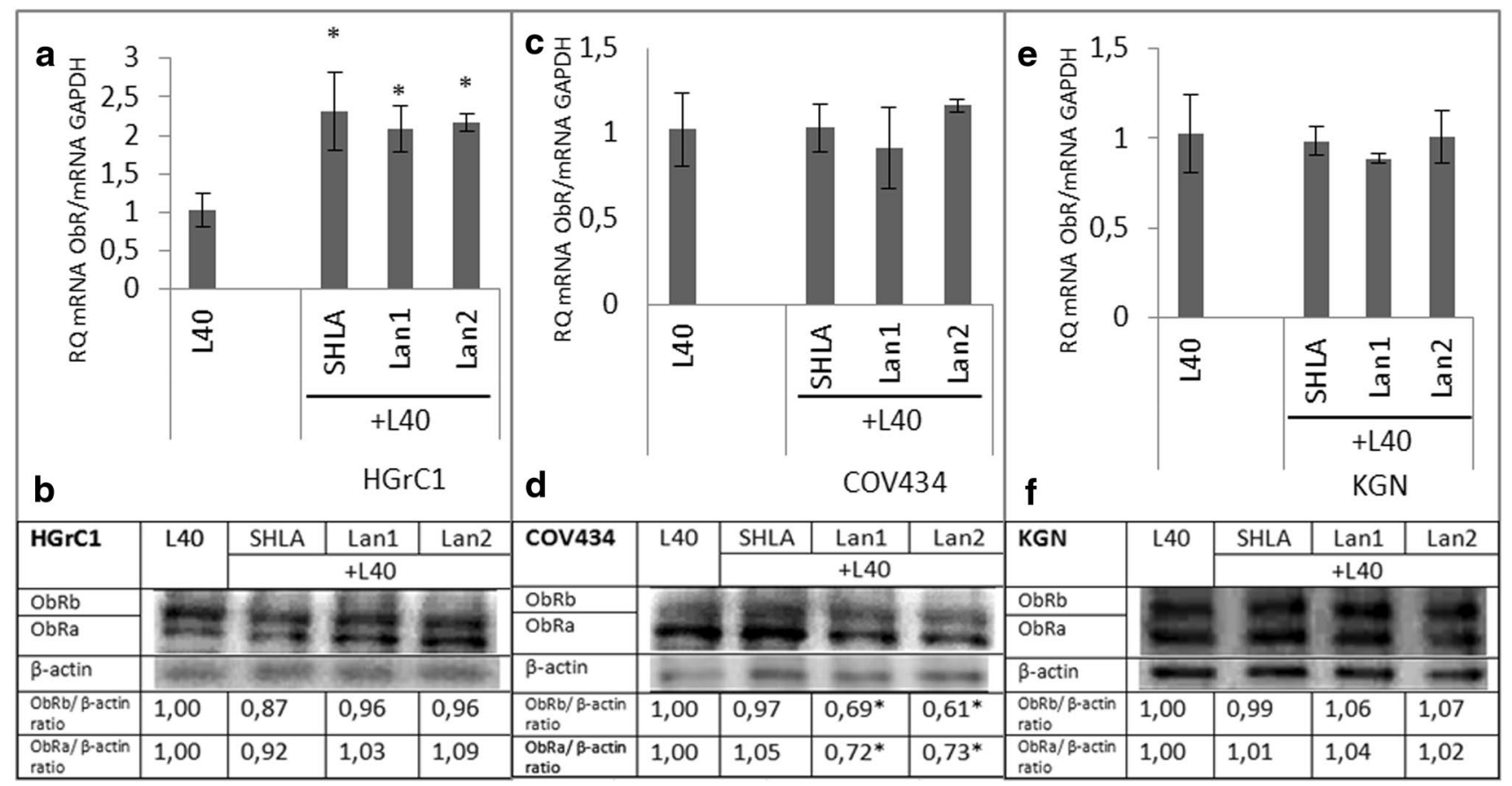

Fig. 2 Effect of leptin receptor antagonists (SHLA, Lan1 and Lan2) on leptin receptor $(\mathrm{ObR})$ gene $(\mathbf{a}, \mathbf{c}, \mathbf{e})$ and protein $(\mathbf{b}, \mathbf{d}, \mathbf{f})$ expression. All values marked with $*(p<0.05)$ are significantly different from control values. Values are mean \pm SEM. Densitometry results were normalised to $\beta$-actin loading controls

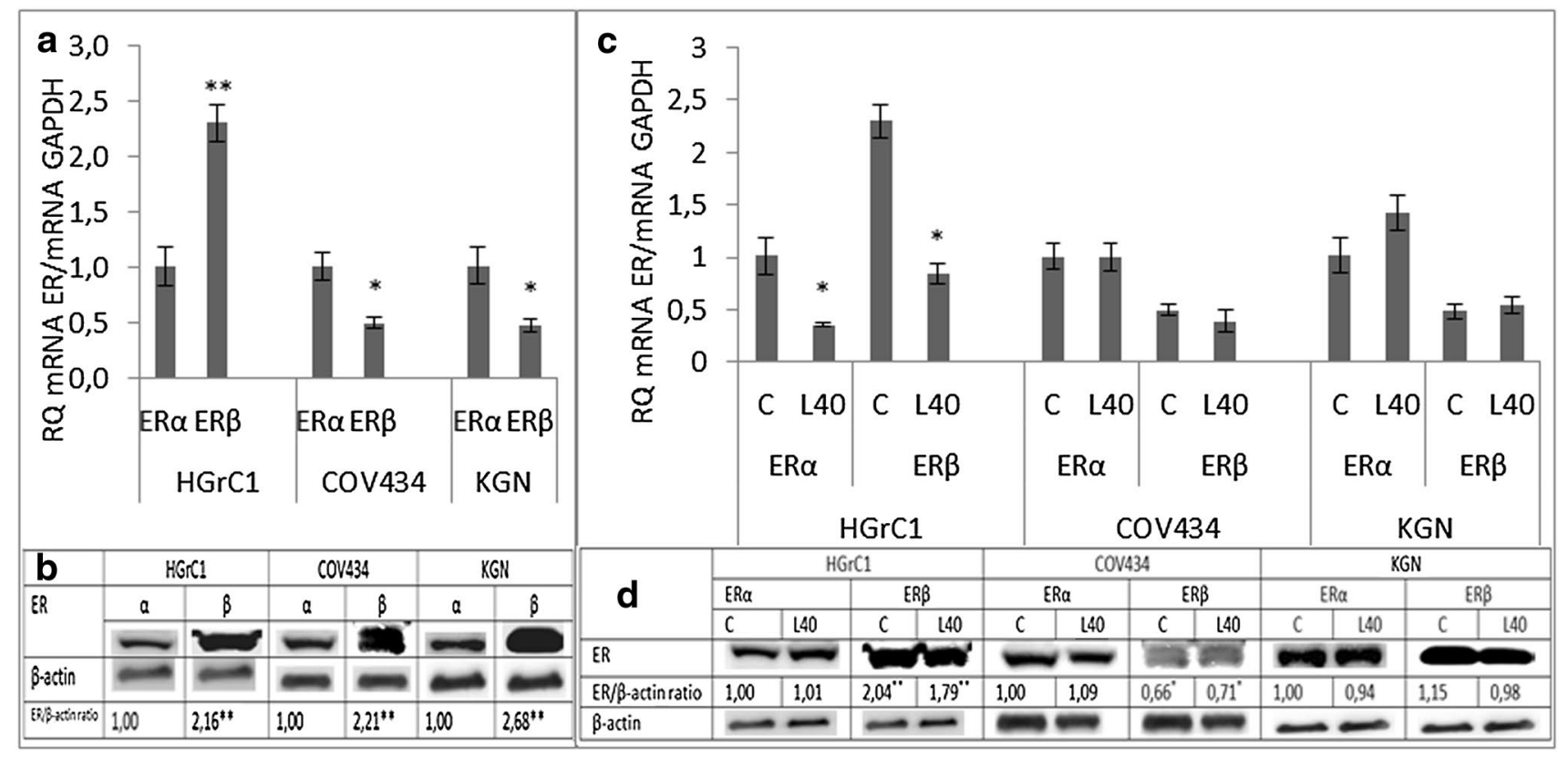

Fig. 3 Expression of the oestrogen receptor (ER) $\alpha$ and $\beta$ forms at a the gene and $\mathbf{b}$ protein levels in different cell lines and the action of leptin on ER $\mathbf{c}$ gene and $\mathbf{d}$ protein expression. Each point represents the mean \pm SEM from three independent experiments. All values marked with $*(p<0.05)$ and $* *(p<0.01)$ are significantly different between $\operatorname{ER} \alpha$ and $\operatorname{ER} \beta(\mathbf{a}, \mathbf{b})$ or from control values $(\mathbf{c}, \mathbf{d})$. All values marked with $*(p<0.05)$ and $* *(\mathrm{p}<0.01)$ are significantly different from control values. Densitometry results were normalised to $\beta$-actin loading controls 


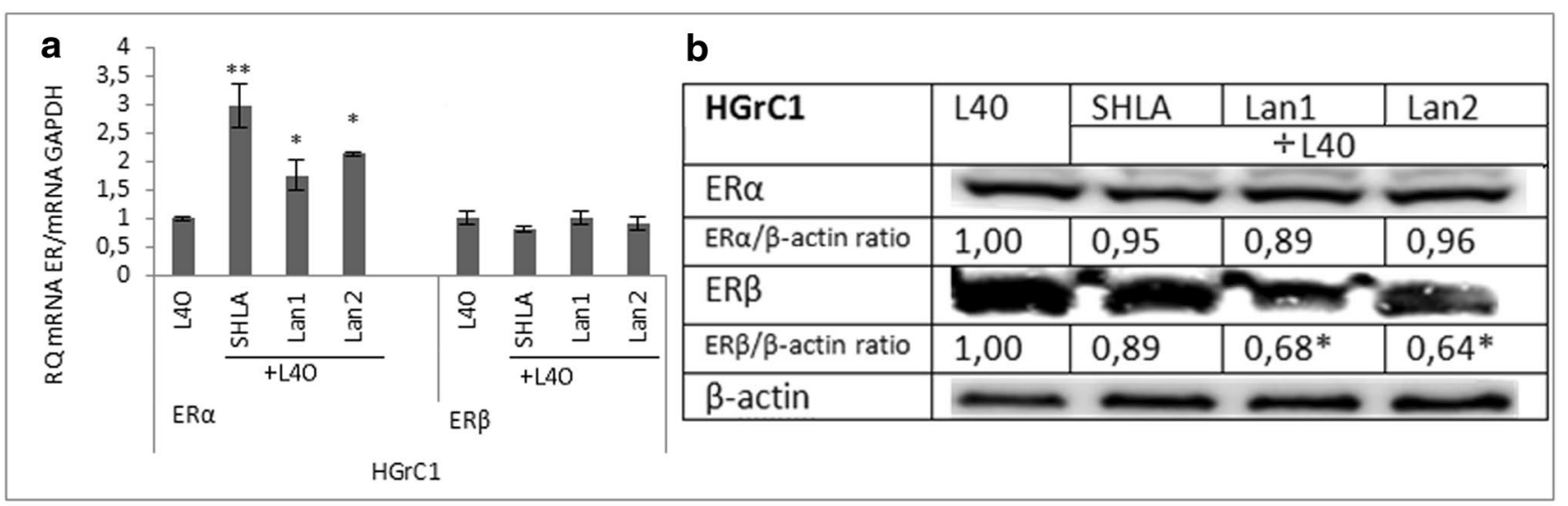

\begin{tabular}{|c|c|c|c|c|c|c|c|c|c|c|}
\hline \multirow{8}{*}{ 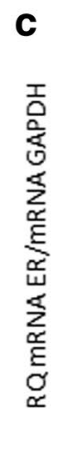 } & \multirow{5}{*}{$\begin{array}{l}1,8 \\
1,6 \\
1,4 \\
1,2 \\
1 \\
0,8 \\
0,6 \\
0,4 \\
0,2 \\
0\end{array}$} & & \multirow{5}{*}{$T$} & \multirow{5}{*}{$I$} & & \multicolumn{5}{|l|}{ d } \\
\hline & & & & & & \multirow[t]{2}{*}{ COV434 } & \multirow[t]{2}{*}{ L40 } & SHLA & Lan1 & Lan2 \\
\hline & & & & & & & & \multicolumn{3}{|c|}{$\div \mathrm{L} 40$} \\
\hline & & & & & & $\mathrm{ER} \alpha$ & \multicolumn{4}{|c|}{ 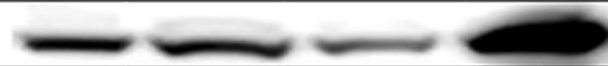 } \\
\hline & & & & & & $E R \alpha / \beta$-actin ratio & 1,00 & 0,79 & $0,52 * *$ & $2,45 * *$ \\
\hline & & O $\leqq \stackrel{1}{=}$ & $\stackrel{N}{\simeq}$ & \multirow{2}{*}{ 肙䍃哥 } & \multirow{2}{*}{$\stackrel{\text { N }}{\underset{త ్}{ \pm}}$} & ER $\beta$ & & & 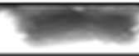 & 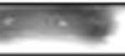 \\
\hline & & I $\stackrel{I}{\omega}$ & $\stackrel{\Xi}{త}$ & & & ER $\beta / \beta$-actin ratio & 1,00 & $0,71 *$ & 0,90 & 0,79 \\
\hline & & $E R \alpha$ & & ER ${ }^{+}+40$ & & $\beta$-actin & $=$ & 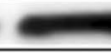 & 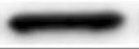 & \\
\hline
\end{tabular}

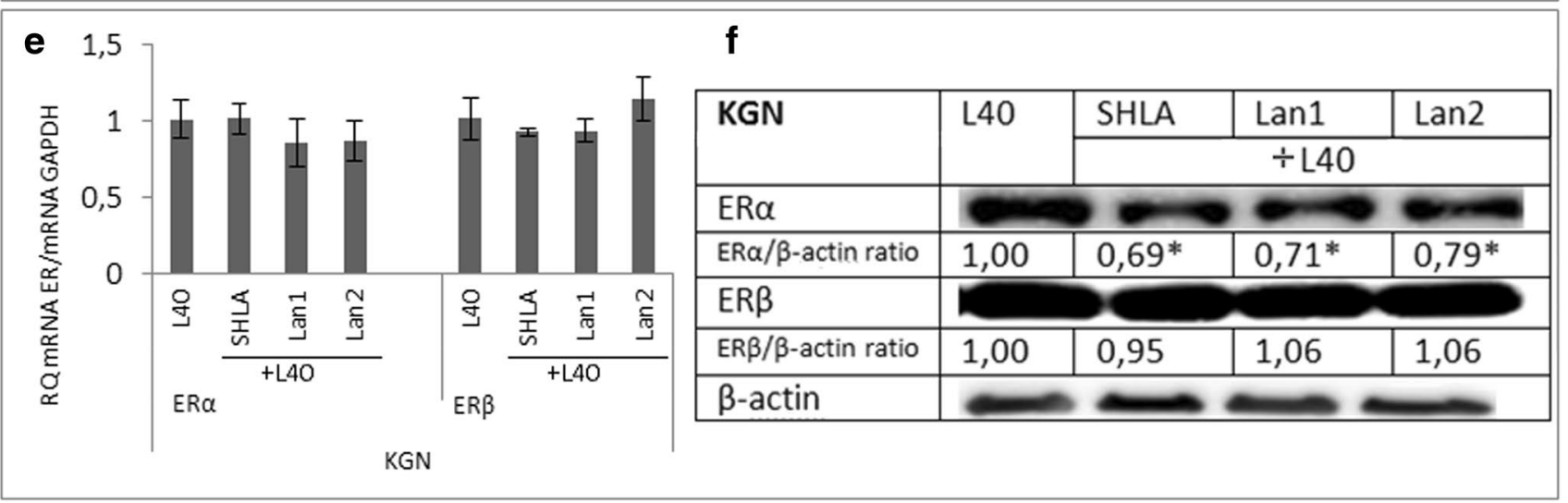

Fig. 4 Effect of leptin receptor antagonists (SHLA, Lan1 and Lan2) on the expression of the oestradiol receptor $\alpha$ and $\beta$ forms on the gene $(\mathbf{a}, \mathbf{c}, \mathbf{e})$ and protein $(\mathbf{b}, \mathbf{d}, \mathbf{f})$ level. Values are mean \pm SEM. All val- ues marked with $*(p<0.05)$ and $* *(p<0.01)$ are significantly different from control values

Effect on leptin receptor antagonists on selected cell cycle protein expression

In $\mathrm{HGrC} 1$ cells, leptin increased $\mathrm{cdk} 4$ and cdk2 protein expression and had no effect on cyclin D1 and A2. No effect on E2F1 or E2 was observed. Of the investigated leptin receptor blockers, SHLA had no effect on selected cell cycle gene or protein expression. An inhibitory effect on 


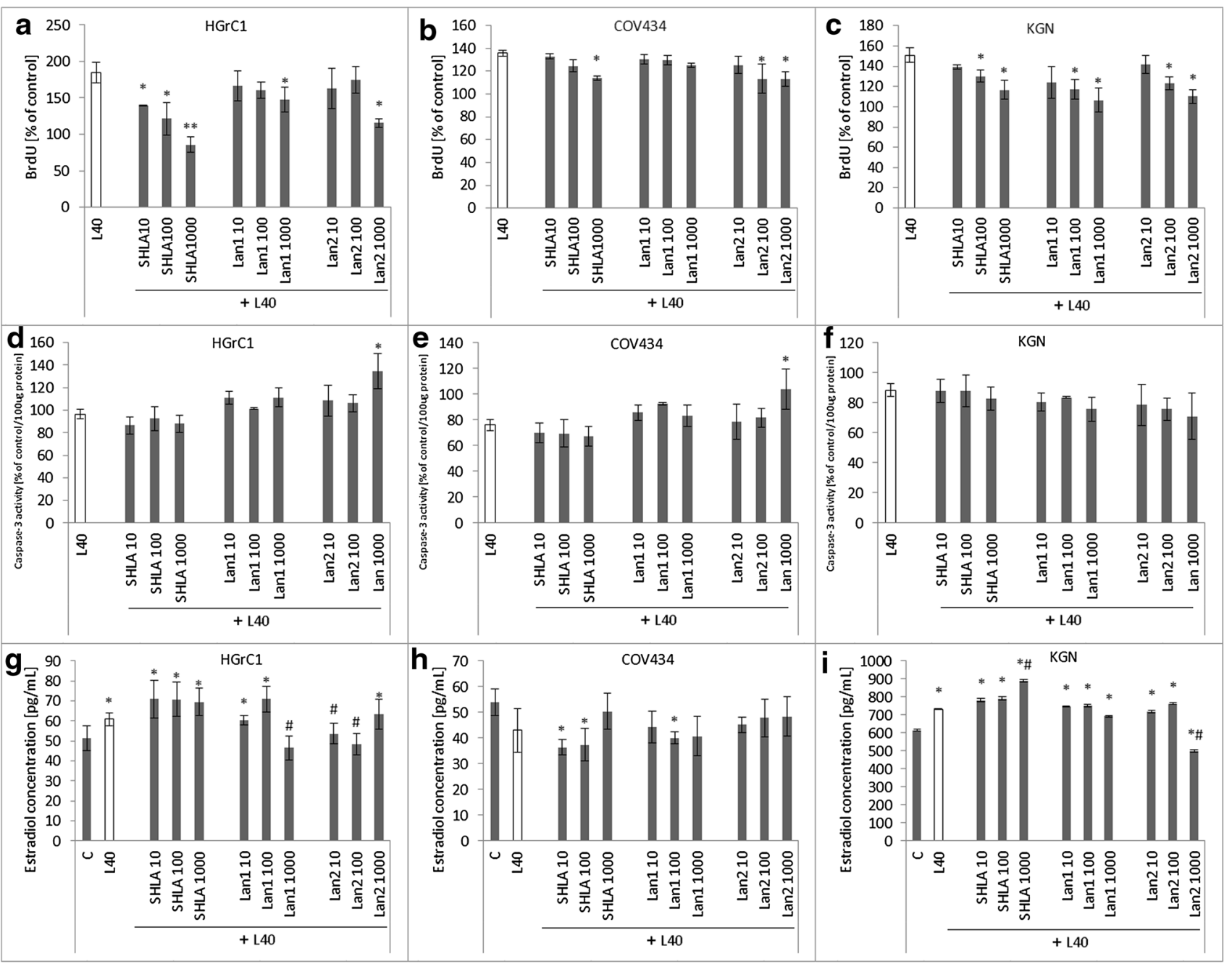

Fig. 5 Effect of leptin and leptin receptor antagonists (SHLA, Lan1 and Lan2) on a-c cell proliferation (BrdU incorporation), $\mathbf{d}-\mathbf{f}$ caspase-3 activity and $\mathbf{g}-\mathbf{i}$ oestradiol secretion. Each point represents the mean \pm SEM from three independent experiments of four repli- cates per treatment group. In a-f, values marked with $*(p<0.05)$ and $* *(p<0.01)$ are significantly different from leptin values. In $\mathbf{g}-\mathbf{i}$, values marked with $*$ are significantly different from control, while those indicated by ${ }^{\#}(p<0.05)$ are significantly different from leptin cdk4 but not cyclin D was noted under the influence of Lan1. A marked inhibitory effect on cyclin A and cdk4 protein expression under the influence of Lan2 was noted. None of the antagonists investigated had an effect on E2F1 or E2 (Fig. 6a).

In COV434 cells, leptin with the exception of a stimulatory effect on E2F2 had no effect on the expression of any other investigated cell cycle proteins. All three leptin receptor blockers decreased cyclin D1 and cdk4 in the following order: SHLA < Lan $1<$ Lan2. In addition, SHLA decreased cyclin A2 protein expression, Lan1 cyclin A2 and cdk2 expression, and Lan 2 cdk 2 protein expression. Of the three blockers studied here, only Lan2 had an inhibitory effect on E2F2 expression (Fig. 6b).

In KGN cells, leptin, with the exception of a slight inhibitory effect on cdk2, had no effect on the expression any of the cell cycle proteins studied. All three blockers decreased the expression of cyclin D1 and cdk2, while Lan2 also reduced cdk 4 expression and both Lan 1 and Lan 2 reduced E2F1 protein.

\section{Discussion}

This study clearly demonstrates twofold higher leptin receptor gene and protein expression in cancer granulosa cell lines compared to non-cancer cell lines. Additionally, we found that leptin increased its own receptor gene expression only in cancer cell lines.

These results on both the short (ObRa) and long (ObRb) forms of the leptin receptor are in agreement with other studies demonstrating both forms of the leptin receptor in 


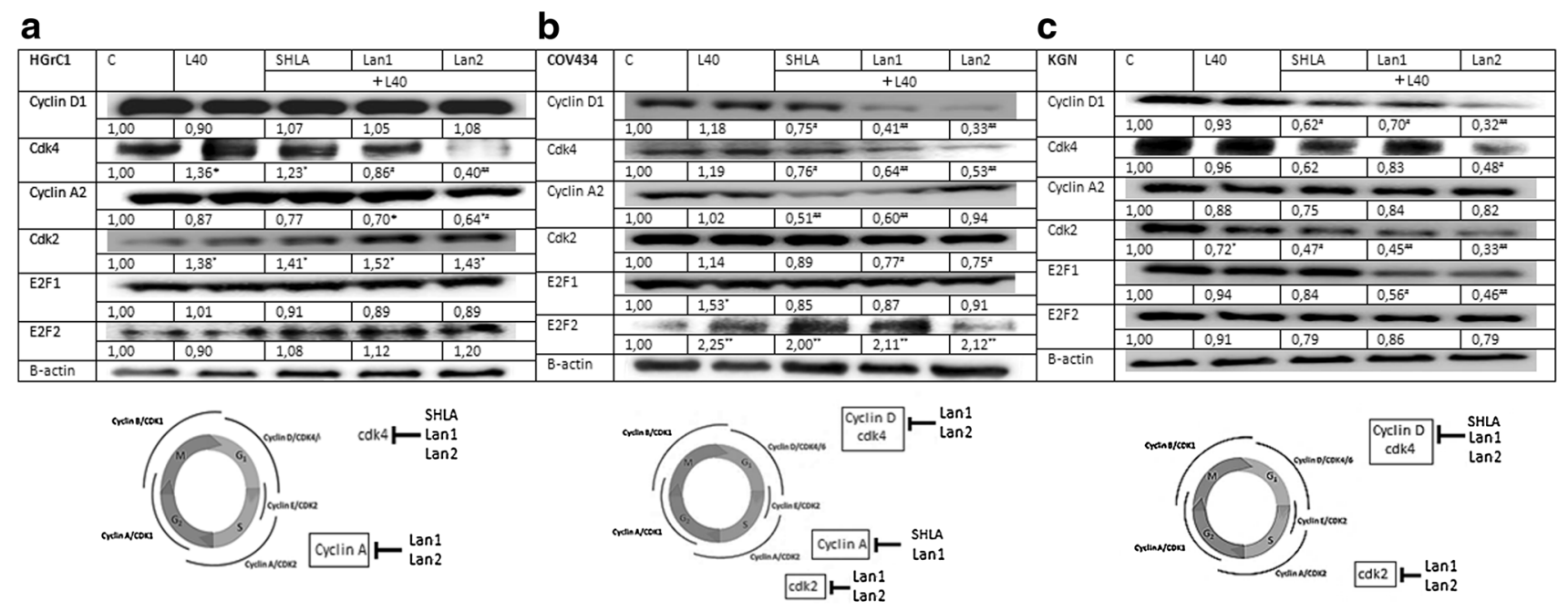

Fig. 6 Expression of cell cycle proteins in $\mathrm{HGrC1}$, COV434 and KGN cell lines under the influence of leptin and leptin receptor antagonists. The representative blots of three experiments are shown in the panels. Cdk2, cyclin A, cdk4, cyclin D and E2F1 densitometry results were normalised to GAPDH loading controls to obtain band ratios. Values are mean \pm SEM. All values marked with $*(p<0.05)$, $* *(p<0.01)$ are significantly different from untreated control values. All values marked with ${ }^{\#}(p<0.05),{ }^{\# \#}(p<0.01)$ are significantly different from the values of leptin at $40 \mathrm{ng} / \mathrm{mL}$

the activation of oestrogen receptor alpha (ER $\alpha)$ through the MAPK pathway in MCF-7 and HeLa cells [31]. In ER+ MCF-7 cells, chronic exposure to leptin has been found to result in a higher ER $\alpha / E R \beta$ ratio, enhanced oestrogen transcriptional activity, greater cell growth and resistance to the anti-oestrogen compound tamoxifen [32].

It is well known that leptin can directly affect ovarian function by its action on oestradiol secretion [33]. There have been a few studies on blocking leptin activity in the ovary and interactions with oestradiol secretion. Our results show that the leptin receptor antagonists SHLA and Lan1, at concentrations of $100 \mathrm{ng} / \mathrm{mL}$, increased oestradiol (E2) secretion by the $\mathrm{HGrC1}$ cell line, but had no effect on oestradiol secretion in granulosa cancer cells (except for Lan2, which decreased E2 secretion in KGN cells). The effect on $\mathrm{ER} \alpha$ and $\mathrm{ER} \beta$ expression was variable in this study. In $\mathrm{HGrC} 1$ cells, all antagonists decreased ER $\beta$ gene expression, but only Lan 1 and Lan 2 decreased protein levels. The blockers SHLA and Lan 1 decreased ER $\alpha$ in juvenile COV434 cells, while Lan 1 and Lan 2 had an effect in adult form KGN cells. These results suggest that, independently of the magnitude of ER $\alpha$ expression, Lan1 was sufficient in both types of cells. Our data are in agreement with Fusco et al. [19], who showed that leptin receptor silencing in MCF-7 breast cancer cells results in decreased ER $\alpha$ expression. The same authors reported that higher leptin levels are more strongly correlated with ER+ breast cancer rather than ER-. In another study, Dupuis et al. [11] used the leptin receptor antagonist PEG-SMLA to demonstrate that inhibition of ObR impaired follicle rupture without affecting meiotic maturation of oocytes in ovarian follicles. 
Leptin, via direct action through $\mathrm{ObR}$ and additionally by enhancing the activation of oestrogen receptor alpha (ER $\alpha)$ through the MAPK pathway, induces cell proliferation. The data presented here show that leptin at a supraphysiological level induced cell proliferation in all investigated cell types, with the greatest effect observed in the normal granulosa cell line $\mathrm{HGrC} 1$ where proliferation reached $180 \%$ of the control. The mutagenic effect of leptin has been observed in various cell types, including breast cancer [33, 34], endometrial cancer [35] and prostate cancer cells [25]. Kato et al. [36] showed that higher leptin levels (above $100 \mathrm{ng} / \mathrm{mL}$ ) or longer incubation times are required to have an effect on proliferation. However, Fiedor and Gregoraszczuk [14] and Ptak et al. [37], using the same leptin concentration, described a similar effect on the proliferation of epithelial ovarian cancer cells.

All ObR antagonists used in this study reversed the leptin-stimulatory effects on cell proliferation, although with varying degrees of success. In non-cancerous $\mathrm{HGrC1}$ cells, the most potent antagonist was SHLA. In KGN cells, all three antagonists at all concentrations reversed leptin-stimulated proliferation. Surprisingly, in the COV434 cell line, the effects of blockers were negligible. The use of leptin receptor antagonists has been well studied in breast cancer. There are reports of the inhibitory action of Aca- 1 and Alloaca on leptin-stimulated proliferation of MCF-7 and MDAMB231 breast cancer cells [15], and D-Ser and DDD on the proliferation of MCF-7 cells [38]. Catalano et al. [16], using LDFI (leptin binding site I), showed the inhibitory effects on the leptin-induced growth of ER $\alpha$-positive (MCF-7) and ER $\alpha$-negative (SKBR3) breast cancer cells. Fusco et al. [19] demonstrated the inhibitory effects of a neutralising monoclonal antibody (9F8) on cell proliferation in the ER-positive MCF-7 cell line, but not in MDA-MB231 ER-negative cells. We previously described SHLA and Lan2 as a promising treatment for epithelial ovarian cell tumours [14]. To our knowledge, these are the first findings to indicate the possible use of ObR blockers in the treatment of folliculoma cancer.

Our results reveal that leptin at $40 \mathrm{ng} / \mathrm{mL}$ does not affect caspase-3 activity in non-luteinising cells $\mathrm{HGrC1}$, but could decrease it in COV434 cells and to a small extent in KGN cells. Using granulosa cells, Sirotkin et al. [39] showed a stimulatory effect of leptin at a dose of $100 \mathrm{ng} /$ $\mathrm{mL}$ on Bax protein in human granulosa cells, suggesting that leptin can modulate apoptosis in human ovaries. The discrepancy in the findings may be due to the different concentrations of leptin. All the antagonists investigated here had no effect on caspase-3 activity in $\mathrm{HGrC1}$ or KGN cells. Only Lan1 and Lan2, at the highest concentrations, restored caspase- 3 activity close to the control level in COV434 cells. Previous experiments conducted in our laboratory have shown that, in epithelial ovarian tumours, leptin at $40 \mathrm{ng} / \mathrm{mL}$ alone or in combination of SHLA or Lan2 does not affect the activity of caspase- $3,-8$ or -9 (unpublished data).

With regard to the mechanism of action of the ObR antagonists, we showed that, in non-cancer HGrC1 cells, Lan1 and Lan2 decreased the expression of cyclin A2 and cdk4. In COV434 cells, all tested antagonists decreased cyclin D1 and cdk 4 protein expression, while Lan 1 also decreased cyclin A2 and cdk2, SHLA had an inhibitory effect on cyclin A, and Lan2 inhibited cdk2 expression. It is generally believed that the critical function of the cyclin A-Cdk2 complex is the phosphorylation of substrates that start DNA replication and co-ordinate the end of S-phase [40]. In KGN cells, only cyclin D1 and cdk2 were decreased by all leptin receptor blockers. Additionally, we observed an inhibitory effect of Lan 1 and Lan2 on the expression of the transcription factor E2F1, suggesting that the anti-proliferative effect of this antagonist in ovarian cancer may be mediated, in part, by the down-regulation of E2F1. Our previously published results [14] concerning the action of leptin receptor antagonists on epithelial ovarian cancer cells showed that both antagonists studied decreased cdk2 and cdk4 protein expression in CaOV-3 and OVCAR-3 cells. Additionally, in CaOV-3 cells, cyclin D1 expression decreased under the influence of SHLA and Lan2.

In summary, (1) in juvenile form of folliculoma, SHLA and Lan-1 increased ER $\beta$ expression, while in the adult form all blockers decreased ER $\alpha$ expression. As a consequence, the ratio moved towards greater expression of ER $\beta$, characteristic of non-cancer granulosa cells. (2) In both types of folliculoma, Lan1 and Lan2 acted as inhibitors of cyclinD/ cdk4, cdk2 and E2F. The ability of these cyclins to activate the cyclin-dependent kinase CDK4 is the most extensively documented mechanism for their oncogenic actions and provides an attractive therapeutic target.

In conclusion, taking into consideration that these results are based on experiments performed on cell lines, and did not consider the tumour microenvironment, further studies should be performed using explants of granulosa cancer from patients with folliculoma or the coculture of granulosa cancer cell line with fibroblasts, epithelial cells and other components of the tumour environment.

Acknowledgements This study was supported by K/ZDS/006310, K/DSC/003955, DS/MND/WBiNoZ/IZ/15/2016 and Jagiellonian University in Kraków, Poland.

\section{Compliance with ethical standards}

Conflict of interest The authors declare that they have no conflicts of interest.

Ethical approval This article does not contain any studies with human participants or animals performed by any of the authors. 
Open Access This article is distributed under the terms of the Creative Commons Attribution 4.0 International License (http://creativecommons.org/licenses/by/4.0/), which permits unrestricted use, distribution, and reproduction in any medium, provided you give appropriate credit to the original author(s) and the source, provide a link to the Creative Commons license, and indicate if changes were made.

\section{References}

1. Garofalo C, Surmacz E (2006) Leptin and cancer. J Cell Physiol 207:12-22

2. Leitzmann MF, Koebnick C, Danforth KN, Brinton LA, Moore SC, Hollenbeck AR, Schatzkin A, Lacey JV Jr (2009) Body as index and risk of ovarian cancer. Cancer 15:812-822

3. Owecki M, Nikisch E, Miczke A, Pupek-Musialik D, Sowiński J (2010) Leptin, soluble leptin receptors, free leptin index, and their relationship with insulin resistance and BMI: high normal BMI is the threshold for serum leptin increase in humans. Horm Metab Res 42:585-589

4. Considine RV, Sinha MK, Heiman ML, Kriauciunas A, Stephens TW, Nyce MR, Ohannesian JP, Marco CC, McKee LJ, Bauer TL et al (1996) Serum immunoreactive-leptin concentrations in normal-weight and obese humans. N Engl J Med 334:292-295

5. Olsen CM, Green AC, Whiteman DC, Sadeghi S, Kolahdooz F, Webb PM (2007) Obesity and the risk of epithelial ovarian cancer: a systematic review and meta-analysis. Eur J Cancer 43:690-709

6. Zhang B, Cai FF, Zhong XY (2011) An overview of biomarkers for the ovarian cancer diagnosis. Eur J Obstet Gynecol Reprod Biol 158:119-123

7. Uddin S, Bu R, Ahmed M, Abubaker J, Al-Dayel F, Bavi P, AlKuraya KS (2009) Overexpression of leptin receptor predicts an unfavorable outcome in Middle Eastern ovarian cancer. Mol Cancer 18:8-74

8. Sikora-Szczęśniak DL, Szczęśniak G, Sikora W (2013) Treatment of ovarian germ cell and gonadal tumors in the gynecology and obstetrics department. Curr Gynecol Oncol 11:264-273

9. Kottarathil VD, Antony MA, Nair IR, Pavithran K (2013) Recent advances in granulosa cell tumor ovary: a review. Indian J Surg Oncol 4:37-47

10. Löffler S, Aust G, Köhler U, Spanel-Borowski K (2001) Evidence of leptin expression in normal and polycystic human ovaries. Mol Hum Reprod 7:1143-1149

11. Dupuis L, Schuermann Y, Cohen T, Siddappa D, Kalaiselvanraja A, Pansera M, Bordignon V, Duggavathi R (2013) Role of leptin receptors in granulosa cells during ovulation. Reproduction 147:221-229

12. Gregoraszczuk EŁ, Rak-Mardyła A (2013) Supraphysiological leptin levels shift the profile of steroidogenesis in porcine ovarian follicles toward progesterone and testosterone secretion through increased expressions of CYP11A1 and 17b-HSD: a tissue culture approach. Reproduction 145:311-317

13. Gertler A, Solomon G (2013) Leptin-activity blockers: development and potential use in experimental biology and medicine. Can J Physiol Pharmacol 91:873-882

14. Fiedor E, Gregoraszczuk EŁ (2016) The molecular mechanism of action of superactive human leptin antagonist (SHLA) and quadruple leptin mutein Lan-2 on human ovarian epithelial cell lines. Cancer Chemother Pharmacol 78:611-622

15. Otvos L Jr, Kovalszky I, Scolaro L, Sztodola A, Olah J, Cassone M, Knappe D, Hoffmann R, Lovas S, Hatfield MP, Beko G, Zhang S, Wade JD, Surmacz E (2011) Peptide-based leptin receptor antagonists for cancer treatment and appetite regulation. Biopolymers 96:117-125
16. Catalano S, Leggio A, Barone I, De Marco R, Gelsomino L, Campana A, Malivindi R, Panza S, Giordano C, Liguori A, Bonofiglio D, Liguori A, Andò S (2015) A novel leptin antagonist peptide inhibits breast cancer growth in vitro and in vivo. $\mathrm{J}$ Cell Mol Med 19:1122-1132

17. Samuel-Mendelsohn S, Inbar M, Weiss-Messer E, Niv-Spector L, Gertler A, Barkey RJ (2011) Leptin signaling and apoptotic effects in human prostate cancer cell lines. Prostate 71:929-945

18. Gao Q, Horvath TL (2008) Cross-talk between estrogen and leptin signaling in the hypothalamus. Am J Physiol Endocrinol Metab 294:E817-E826

19. Fusco R, Galgani M, Procaccini C, Franco R, Pirozzi G, Fucci L, Laccetti P, Matarese G (2010) Cellular and molecular crosstalk between leptin receptor and estrogen receptor- $\{$ alpha $\}$ in breast cancer: molecular basis for a novel therapeutic setting. Endocr Relat Cancer 17:373-382

20. Niv-Spector L, Gonen-Berger D, Gourdou I, Biener E, Gussakovsky EE, Benomar Y, Ramanujan KV, Taouis M, Herman B, Callebaut I, Djiane J, Gertler A (2005) Identification of the hydrophobic strand in the A-B loop of leptin as major binding site III: implications for large-scale preparation of potent recombinant human and ovine leptin antagonists. Biochem $\mathrm{J}$ 391:221-230

21. Bayasula IA, Kiyono T, Takikawa S, Goto M, Nakamura T, Nagatomo Y, Nakahara T, Kotani T, Kobayashi H, Kondo M, Manabe S, Kikkawa F (2012) Establishment of a human nonluteinized granulosa cell line that transitions from the gonadotropin-independent to the gonadotropin-dependent status. Endocrinology 153:2851-2860

22. Zhang H, Vollmer M, De Geyter M, Litzistorf Y, Ladewig A, Dürrenberger M, Guggenheim R, Miny P, Holzgreve W, De Geyter C (2000) Characterization of an immortalized human granulosa cell line (COV434). Mol Hum Reprod 6:146-153

23. Nishi Y, Yanase T, Mu Y, Oba K, Ichino I, Saito M, Nomura M, Mukasa C, Okabe T, Goto K, Takayanagi R, Kashimura Y, Haji M, Nawata H (2001) Establishment and characterization of a steroidogenic human granulosa-like tumor cell line, KGN, that expresses functional follicle-stimulating hormone receptor. Endocrinology 142:437-445

24. Karlsson C, Lindell K, Svensson E, Bergh C, Lind P, Billig H, Carlsson LM, Carlsson B (1997) Expression of functional leptin receptors in the human ovary. J Clin Endocrinol Metab 82:4144-4148

25. Stattin P, Söderberg S, Hallmans G, Bylund A, Kaaks R, Stenman UH, Bergh A, Olsson T (2001) Leptin is associated with increased prostate cancer risk: a nested case-referent study. J Clin Endocrinol Metab 86:1341-1345

26. Cuello-Fredes M, Kato S, Abarzúa-Catalán L, Delpiano A, Trigo C, García K, Sanhueza C, Ibañez C, Brañes J, Castellon E, Owen G (2015) Leptin promotes a more aggressive behavior of ovarian cancer cells: a potential explanation for a worse prognosis in obese ovarian cancer patients: igcs-0095 ovarian cancer. Int J Gynecol Cancer 25(Suppl 1):67

27. Ray A, Nkhata KJ, Cleary MP (2007) Effects of leptin on human breast cancer cell lines in relationship to estrogen receptor and HER2 status. Int J Oncol 30:1499-1509

28. Ozbay T, Nahta R (2008) A novel unidirectional cross-talk from the insulin-like growth factor-I receptor to leptin receptor in human breast cancer cells. Mol Cancer Res 6:1052-1058

29. Pfaff D, Keiner M (1973) Atlas of estradiol-concentrating cells in the central nervous system of the female rat. J Comp Neurol $15: 121-158$

30. Bulun SE, Chen D, Moy I, Brooks DC, Zhao H (2012) Aromatase, breast cancer and obesity: a complex interaction. Trends Endocrinol Metab 23:83-89 
31. Lau WS, Chen WF, Chan RY, Guo DA, Wong MS (2009) Mitogen-activated protein kinase (MAPK) pathway mediates the oestrogen-like activities of ginsenosides $\operatorname{Rg} 1$ in human breast cancer (MCF-7) cells. Br J Pharmacol 156:1114-1136

32. Valle A, Sastre-Serra J, Oliver J, Roca P (2011) Chronic leptin treatment sensitizes MCF-7 breast cancer cells to estrogen. Cell Physiol Biochem 28:823-832

33. Yin N, Wang D, Zhang H, Yi X, Sun X, Shi B, Wu H, Wu G, Wang X, Shang Y (2004) Molecular mechanisms involved in the growth stimulation of breast cancer cells by leptin. Cancer Res 64:5870-5875

34. Barone I, Catalano S, Gelsomino L, Marsico S, Giordano C, Panza S, Bonofiglio D, Bossi G, Covington KR, Fuqua SA, Andò S (2012) Leptin mediates tumor-stromal interactions that promote the invasive growth of breast cancer cells. Cancer Res 72:1416-1427

35. Sharma D, Saxena NK, Vertino PM, Anania FA (2006) Leptin promotes the proliferative response and invasiveness in human endometrial cancer cells by activating multiple signal-transduction pathways. Endocr Relat Cancer 13:629-640
36. Kato S, Abarzua-Catalan L, Trigo C, Delpiano A, Sanhueza C, García K, Ibañez C, Hormazábal K, Diaz D, Brañes J, Castellón E, Bravo E, Owen G, Cuello MA (2015) Leptin stimulates migration and invasion and maintains cancer stem-like properties in ovarian cancer cells: an explanation for poor outcomes in obese women. Oncotarget 6:21100-21119

37. Ptak A, Kolaczkowska E, Gregoraszczuk EL (2013) Leptin stimulation of cell cycle and inhibition of apoptosis gene and protein expression in OVCAR-3 ovarian cancer cells. Endocrine 43:394-403

38. Beccari S, Kovalszky I, Wade JD, Otvos L Jr, Surmacz E (2013) Designer peptide antagonist of the leptin receptor with peripheral antineoplastic activity. Peptides 44:127-134

39. Sirotkin AV, Mlyncek M, Makarevich AV, Florkovicová I, Hetényi L (2008) Leptin affects proliferation-, apoptosis- and protein kinase A-related peptides in human ovarian granulosa cells. Physiol Res 57:437-442

40. Dietrich C, Kaina B (2010) The aryl hydrocarbon receptor (AhR) in the regulation of cell-cell contact and tumor growth. Carcinogenesis 31:1319-1328 